\title{
Origen of Alexandria: The study of the Scriptures as transformation of the readers into images of the God of love
}

\author{
Author: \\ Paul B. Decock ${ }^{1,2}$ \\ Affiliations: \\ ${ }^{1}$ School of Religion and \\ Theology Department, \\ University of KwaZulu-Natal, \\ South Africa \\ ${ }^{2}$ St. Joseph's Theological \\ Institute, Cedara, South Africa \\ Correspondence to: \\ Paul Decock \\ email: \\ decock@sjti.ac.za \\ Postal address: \\ St. Joseph's, Private Bag \\ 6004, Hilton 3245, \\ South Africa \\ Dates: \\ Received: 25 May 2010 \\ Accepted: 09 Sept. 2010 \\ Published: 07 June 2011 \\ How to cite this article: \\ Decock, P.B., 2011, \\ 'Origen of Alexandria: The \\ study of the Scriptures \\ as transformation of the \\ readers into images of \\ the God of love', HTS \\ Teologiese Studies/ \\ Theological Studies 67(1), \\ Art. \#871, 8 pages. DOI: \\ $10.4102 /$ hts.v67i1.871
}

(C) 2011. The Authors. Licensee: OpenJournals Publishing. This work is licensed under the Creative Commons Attribution License.
For Origen, the purpose of reading the Scriptures is to be transformed more and more into the likeness of God, who is Love, through the Logos embodied in the Scriptures. This article first situated Origen's approach to the Scriptures in the broad agreement over the centuries that the Scriptures are meant to address the present readers and not merely the original readers. This has led to various approaches to actualise the text up to the present varieties of contextual exegesis. Secondly, the article showed how, for Origen, the aim of actualising the text is the transformation of the readers. It will be necessary, therefore, to briefly present some of the key aspects of Origen's pre-understanding. The third part focused on Origen's understanding of the reading process as a movement from the letter to the spirit, a process that involves the transformation of the reader. This process is a struggle to understand what love, which is both the mystery of God and the aim for which every being is created through the Logos, is.

\section{Introduction}

Reflecting on one of the great pioneers of biblical interpretation in the Early Church's approach to the Scriptures is no doubt a suitable way to honour the work of Professor Andries van Aarde, who, in our context, continued that passion and dedication.

\section{The Scriptures as addressed to the present readers}

A first characteristic of the approach to the Scriptures in early Christianity was the conviction that the Scriptures are meant to speak to the actual readers and not just to a past generation. In fact, the sharp distinction between what the text 'meant' and what the text 'means' did not come about until after the contributions of the Religionsgeschichtliche Schule [History of Religions School] as reaction against the liberal interpretation (see Stendahl 1962:418-420). Origen's approach to the Scriptures must be seen in the context of the broad agreement over the centuries that the Scriptures are meant to address the present readers and transform their lives. In order to situate Origen's approach on this trajectory this article looked first at the process of actualisation in the very production of the Scriptures. After the Scriptures were considered as standardised and fixed, the task of interpretation was seen as relating the text to the reader by means of reading and commentary. In the process 'more-than-literal meanings of the text' had to be articulated (see Decock 1993). During the next stage on the trajectory, from the 13th century and especially from the Renaissance onwards, the literal meaning was seen to be the decisive one for the present, especially in view of disputes over doctrine. As a result of the Enlightenment, the literal meaning often became incredible or contested. After the challenge of the Religionsgeschichtliche Schule against the liberal efforts at saving the literal meaning, scholars became more sharply aware of the gap between what the text meant in its context and culture of origin and what it means now in new, contemporary contexts. Whilst it became common from that time onwards to define the task of exegesis as exploring the historical meaning of the text, soon the need was felt again to go beyond this and explore again the meaning of the text for the present readers, in their cultural context. Bultmann, in his demythologising programme and, later on, contextual exegesis with the various forms of liberation and advocacy readings again clearly focussed on the present context (Brown \& Schneiders 1990:1159-1160).

In order to go briefly over this trajectory, Fishbane $(1985,1989)$ will be used as starting point. He shows how the Hebrew Bible 'not only sponsored a monumental culture of textual exegesis but was itself its own first product' (1989:4). He continues: 'it is clear that the authoritative text being explicated was not considered inviolable but subject to the invasion of a tradition of interpretation which rendered it more comprehensible' (1989:5) and concludes:

One may say that the entire corpus of Scripture remains open to these invasive procedures and strategic reworkings up to the close of the canon in the early rabbinic period, and so the received text is complexly compacted of teachings and their subversion, of rules and their extension, of topoi and their revision. 
Within ancient Israel, as long as the textual corpus remained open, Revelation and Tradition were thickly interwoven and interdependent, and the received text of the Bible is itself, therefore, the product of an interpretative tradition.

(Fishbane 1989:18)

This is also the way we have to understand the development of the Gospel material; the aim of the handing on of this material was not merely to preserve, but to make it 'present' in such asa way that it could serve the needs of the communities. Dieter A. Koch (1986:322-326) points out how Paul understood the Scriptures as speaking to the present hearers, for example in 1 Corinthians 9:10; 10:11; Romans 4:23-24; and 15:4. Paul even felt free to 'adjust' the texts of Scripture to bring out more clearly the relevance for the present (Koch 1986:346-347). ${ }^{1}$

Whilst the text of the Scriptures gradually became standardised and more fixed at about the beginning of our era (i.e. 1st century CE), this did not mean that they wanted to capture and fix an 'original' meaning. Both Rabbinical Judaism and Early Christianity continued to see the text as open-ended and to be completed by the right interpretation. Although the letters of Scripture were considered to be fixed, the meaning of Scripture remained open. This is beautifully expressed in the following midrashic comment from Eliyahu Zutta,II, quoted by Fishbane:

When the Holy One, blessed be He, gave the Torah to Israel, He only gave it as wheat from which to extract flour, and as flax wherewith to weave a garment ...2

(Fishbane 1989:37-38)

This imagery suggests that, in order to be useful, the words of the Scriptures need to be worked upon, crushed as the wheat and submitted to a disintegration process like the flax. Origen reverts to similar images in his Homilies on Genesis when he takes the scene of Jesus breaking the bread as an image for the interpretation of the Scriptures:

That is, unless the letter has been discussed and broken into little pieces, its meaning cannot reach everyone. But when we have begun to investigate and discuss each single matter, then the crowds indeed will assimilate as much as they shall be able.

(Hom. Gen. 12; transl. Heine 1982:183)

Patricia Cox Miller (1988:172) also refers to the image of Christ harrowing hell in Origen's De Engastrimutho as an image for the interpreter of the Scriptures: 'However polysemous their potential, words are gates of brass that must be broken by active interpretation; unless so engaged, they remain like iron bars'. This presupposes what Augustine later called the 'mira profunditas' [wonderful depth] of the Scriptures (Confessions 12:14; text O'Donnell 1992:170). This does not mean, however, that the words themselves have this depth on their own, but 1.'The primary concern of the sages, the apocalyptists and the early Christians was not
the original, the literal meaning of Bible, but rather what it had come to mean, i.e. its actualized or contemporized meaning' (Aune 1983:340).

2.Neusner (1984:137), in fact, speaks about 'the always open canon' in rabbinical Judaism: 'The rabbi speaks with authority about the Mishnah and the Scripture. He therefore has authority deriving from revelation. He himself may participate in He therefore has authority deriving from revelation. He himself may participate in the processes of revelation (there is no material difference). Since that is so, the rabbi's book, whether Talmud to the Mishnah or midrash to Scripture, is torah, that is, revealed by God. It also forms part of the Torah, a fully "canonical" document... So in the rabbi, the word of God was made flesh. And out of the union of man and Torah, producing the rabbi as Torah incarnate, was born Judaism, the faith of Torah: the ever-present revelation, the always open canon'. only when read within a revelatory context. ${ }^{3}$ For Qumran, the eschatological context enabled the interpreters to transcend the understanding of the prophets, as the Commentary on Habakuk 2:3a says: 'Its interpretation: the final age will be extended and go beyond all that the prophets say, because the mysteries of God are wonderful' (transl. García Martínez 1994:200). However, only a 'charismatic exegesis' is able to discern this depth. ${ }^{4}$ For Paul, in 1 Corinthians 2:10-16 the revelatory context is established by those who have the mind of Christ. Here too, Paul's focus is on the meaning of the text for the present readers:

these things God has revealed to us through the Spirit; for the Spirit searches everything, even the depths of God. For what human being knows what is truly human except the human spirit that is within? So also no one comprehends what is truly God's except the Spirit of God. Now we have received not the spirit of the world, but the Spirit that is from God, so that we may understand the gifts bestowed on us by God. And we speak of these things in words not taught by human wisdom but taught by the Spirit, interpreting spiritual things to those who are spiritual. Those who are unspiritual do not receive the gifts of God`s Spirit, for they are foolishness to them, and they are unable to understand them because they are spiritually discerned. Those who are spiritual discern all things, and they are themselves subject to no one else's scrutiny. 'For who has known the mind of the Lord so as to instruct him?' But we have the mind of Christ.

(1 Cor 2:10-16)

For Origen, having 'the mind of Christ' in order to be able to understand the Scriptures means that the reader has to be conformed to Christ:

For indeed everyone who has been perfected 'no longer lives, but Christ lives in him', [Gal 2:20] and since 'Christ lives' in him, it is said of him to Mary, 'Behold your son', the Christ. How great, then, must be our understanding that we may be able to understand in a worthy manner the word which is stored up in earthen treasures of paltry language, whose written character is read by all who happen upon it, and whose sound is heard by all who present their physical ears? ... For he who will understand these matters accurately must say truthfully, 'But we have the mind of Christ, that we may know the graces that have been given us by God'.

(Comm. Io. 1:23-24; transl. Heine 1989:38)

Whilst the words of Scripture are hard to penetrate, they are nevertheless enlightening, healing and empowering energies in the lives of those who are properly disposed and approach the text with diligent labour. In his Homilies on Exodus,

3.... the two terms [figure or type and allegory] do not simply describe features of the biblical texts as such (i.e. as a text that has "other meanings" or one that contains "figures" or "types"). Instead, the terms describe the biblical text as it is read by persons who are themselves undergoing the process of spiritual transformation ... (Dawson 1999:365). Augustine's theological interpretation of Scripture is supported by the observation in De Magistro that '... it is more truly said that "the sign is known in the thing" than "the thing is learned from a given sign". At this point the treatise unfolds its essential point that Christ the inner teacher acquaints the soul with the realities behind all signs'. (De Magistro 11.38). Inner experience fills out the meaning of the words, guided by the faith of the Church (Cameron 1999:794; see De Doctrina Christiana, Prologue 3 and Alici 1996:32). We are not convinced by words, but by the things to which the words point; if we have no experience of these things the words will remain empty!

4.On 'charismatic exegesis' and its three essential features, namely that it is a commentary, eschatological and inspired, see Decock (1993:277-280). 
Origen compares the energies of the words of the Scriptures with those of seeds:

I think each word of divine scripture is like a seed whose nature is to multiply diffusely ... Its increase is proportionate to the diligent labor of the skilful farmer or the fertility of the earth

(Hom. Exod. 1:1; quoted by Cox Miller 1988:167-168)

It may be interesting at this point to recall Psalm 119:18LXX,

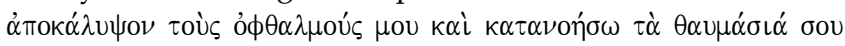

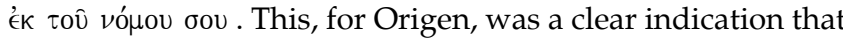
understanding the Scriptures was a process of 'un-veiling,' requiring the purification of our sight and of our whole life. He understood the verse, therefore, as a prayer for the removal of 'every cloud and darkness which obscures the vision of our hearts hardened with the stains of sins' (see Hom. Lev. 1:1,4; transl. Barkley 1990:30). ${ }^{6}$

As can be seen, the understanding that the full meaning of a text is the meaning for the current readers has been the dominant view in the history of Christianity and is, in various forms, very much alive today. Even the historical approach took it for granted that the meaning for today was the historical meaning of the text and a large number of its practitioners saw in it a means of 'purifying' the 'irrational' views of their contemporaries. It was the Religionsgeschichtliche Schule that highlighted the cultural distance between the ancient texts and the contemporary cultures of the readers. The hermeneutical challenge was therefore seen as moving from what the text meant to what the text now means. Origen, a man of his times, did not see the problem as one of cultural distance, but of penetrating the literal meaning to reach the spiritual meaning. This movement from the literal meaning to the spiritual meaning required a process of personal transformation in the reader. ${ }^{7}$

\section{The usefulness of Scripture for human transformation}

Origen approached the Scriptures as divine instruction, that aims at the transformation of the present readers and not merely at information about the past (see 2 Tm 3:16-17). The purpose of reading is that readers will grow in existential wisdom. They are also enabled to progress towards a fuller understanding of the meaning of the text in their own lives to the extent that they grow in that wisdom. We now turn to Origen's understanding of the Christian story of meaning, which provides the framework for this existential wisdom.

\section{Origen's 'Grand Narrative' or his Christian story of meaning}

Origen's approach to the reading and interpretation of the Scriptures is shaped by his understanding of their nature as

5.Cox Miller (1988:168) refers also to Origen's comparison of the words of the Scriptures 'as goads, prodding the beast, the interpreter, to move in the nuanced world that they offer'.

6.It is interesting that Fishbane (1985:539-542) also draws attention to this verse he contrasts this with the warnings in Deuteronomy $29 \cdot 29$ and Sirach 3:20-22 where wondrous knowledge must be understood as 'speculations which involved apocalyptic experiences'.

7.Candler (2006) has shown how, in the Middle Ages, understanding the Scriptures was seen as an 'ascent' of the readers in which they are not alone but are guided by a whole tradition of earlier readers. the embodiment of the Logos. More broadly, his approach is further shaped by his understanding of God, the Logos, the world as God's creation and the goal of the history of this creation. Origen had explored these issues and articulated his understanding by reading the Scriptures under the guidance of the rule of faith. He expressed his perception in particular in response to the different answers given to these questions by philosophers, Gnostic writers and 'simple' Christians. His 'Grand Narrative' can be seen as a response to and a transformation of, the Platonic and Gnostic versions of such a narrative. His positive view of the created reality is crucial and indicates the direction of the whole drama of salvation. God's aim, for Origen, is expressed in the words of 1 Corinthians 15:28: ' $\ldots$ so that God may be all in all'. ${ }^{8}$ The miserable state of the present world was a challenge posited by the Gnostics and Marcion, to which Origen responded by positing a perfect state of creation at the beginning, in which the created intelligences $[\nu 0 \hat{s}]^{9}$ were created in the image of the Logos, the only perfect image of God. In their original perfection, they were fully united with God; God was all in all. However, this original love for God weakened in most ${ }^{10}$ of the created intelligences. The original equality was lost in a hierarchy ranging from angels to demons and Satan (Dively Lauro 2004:101). Human beings were intelligences who had degenerated into 'souls. ${ }^{\prime 11}$ They had fallen from that original unity and love and had become divided in themselves between the higher elements (intellect, heart, governing faculty) and the lower parts (instincts and passions). ${ }^{12}$ Their bodies became mortal and they were placed by God in the present material universe as a merciful means of reform and return to God (Gn 3:21). Origen emphasised the crucial importance of human will and freedom in the process of salvation. In this process the good is 'appropriated' ${ }^{13}$ against the common determinism of Hellenistic culture (astrology) and the Gnostic view, according to which salvation was determined by one's make up (as gnostics, psychics, or hylics). The goal of salvation, to love, can only be a free human act, but an act called forth by the loving approach of Logos, even imagined by Origen as the 'wounding dart of eros' (Comm. Cant. Prologue; transl. Lawson 1957:30). In fact,

8.The Biblia Patristica gives 41 references to this verse in Origen's writings

9.On the form of the plural used by Origen, Crouzel (1989:206) asserts: 'he would certainly not have used the plural noes but noi'.

10.Not all intelligences fell away from unity with God; first of all, there is the one assumed by the Logos (Princ. 2:6; see Crouzel 1989:192); some others may also have remained faithful, but accepted like the one assumed by the Logos to share the condition of the fallen ones in order to save them (Crouzel 1989:211)

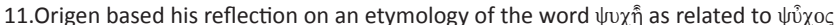
cold (see Princ. 2:8,3-4); see Crouzel (1989:210).

12.'All that corresponds more or less to what later theology would call concupiscence, but only to a degree, for 'the thought of the flesh' means more than the attraction to sin. It contains natural functions, which are not evil in themselves and can be spiritualised without being destroyed, when the intellect adheres to the spirit. Al that is clearly shown by Origen's reflections on the humanity of Christ. ... So the lower part of the soul could not be for Him a source of temptation, but it was a source of distress, sadness and suffering, as the Gospel testifies'(Crouzel 1989:8889).

13.'For the Creator gave, as indulgence to the understandings [Latin: mentes, in this article it is usually translated as 'intelligences'] created by him, the power of free and voluntary actions, by which the good was that was in them might become their own being preserved by the exertion of their own will; but slothfulness and the dislike of labour in preserving what is good and an aversion to and neglect of better things furnished the beginning of a departure from goodness. But to depart from good is nothing else than to be made bad. For it is certain that to want goodness [bono carere] is to be wicked' (Princ. 2:9,2; transl. Crombie 1982:290). On the debate on Origen's appreciation of grace, see O'Leary (2004:114-115). 
the Logos, in his 'suffering' because of the fallen condition of the souls, was moved ${ }^{14}$ to share, in his unfallen soul, the fallen state of humanity. In so doing he could, by the fire of his love, make a holocaust of the flesh to God on the wood of the cross and, in his 'body', reunite the fallen souls. It is this Logos who is embodied in the Scriptures and who now continues to draw all to himself (Jn 12:32). Just as on the cross the incarnate soul of Jesus was glorified by becoming one with the Logos (Comm. Jo. 32:325-326), so this process will extend itself to all humanity (Comm. Jo. 32:400 with reference to Ps 62:9, 'My soul has clung to you'). Through this union, humanity is enabled to return to the ardent love of God as in the original creation. It is in view of this return to the original state that the Scriptures have been given to us.

\section{Transformation of the reader as the purpose of reading the Scriptures}

Modern biblical scholars recognise a variety of outlooks present in the Canon and some have elevated some books as the Canon within the Canon (Brown \& Collins 1990:10521054). Origen, however, tried to accommodate this diversity as a divine educational process. This process of paideia was a lively concern in the Hellenistic world (Marrou 1950:139-313) and Origen clearly interpreted the Scriptures as the Christian version of this paideia. Before him, Philo referred to the Greek educational system and the specific order in which various subjects had to be taught in his interpretation of Genesis $16 .{ }^{15}$ According to Philo, the ultimate aim of education is wisdom or virtue, but Abraham (the soul) is unable to procreate with Sarah (virtue) until he has 'knowledge' of the lower forms represented by the concubine (Hagar): grammar, music, mathematics, geometry, rhetoric, dialectic, astronomy. However, these are only preliminary studies (handmaids) and should never take the place of the true aim (the wife), wisdom and virtue. Similarly, Origen draws our attention to the established order of procedure in the study of philosophy, where the sequence of ethics, physics and enoptics guides him to view the sequence of the three books of Solomon in precisely that order: Proverbs (ethics), Qohelet (physics) and Song of Songs (enoptics). ${ }^{16}$ This provides Origen with the three basic stages of the spiritual growth:

14.Whilst generally Origen will interpret the passions ascribed to God in the Scriptures in a metaphorical sense, '... in his sermons on Ezekiel he deals explicitly with God's caritatis passio, so that he appears to bring about an undeniable contradiction between the divine impassibility and divine passibility. Origin solves this problem by arguing that the "passion of charity" or "philanthropy" must belong to the pre-existent Logos. In fact, it is the very reason for the incarnation' (Fernandez Eyzaguirre 2006:135)

15.For instance, in Mating with Preliminary Studies: 'For some have been ensnared by the love of the lures of the handmaids and spurned the mistress ... some doting on poetry, some on geometrical figures, some on blending of musical colours and a host of other things and have never been able to soar to the winning of the lawful wife (p. 77).... Now philosophy teaches us control of the belly and the parts below wife ( $p$. 77).... Now philosophy teaches us control of the belly and the parts below
it and control also of the tongue. Such powers of control are said to be desirable it and control also of the tongue. Such powers of control are said to be desirable
in themselves, but will assume a grander and loftier aspect if practiced for the honour and service of God (p. 80)' (transl. Colson \& Whitaker 1985:497-498). Origen follows this same line in Philocalia 13.

16.Origen clearly approached the Scriptures in the tradition of philosophy, as can be seen in his introductions to his commentaries. They followed a pattern that was well established in the philosophical schools of Alexandria (see Hadot 1987; Neuschäfer 1987; and Heine 1995). Philo was for him and for Clement befor him, an import meth a method of composing his allegorical treatises is clearly related to exegetica writing (cf. junctis juncture - is that the formal aspects have been drawn from Greek models, whils the manner of invoking and handling the biblical text has a Jewish background (Runia 1987:120).
- moral purification

- recognition of the true value of everything created by God (which brings order in our lives, see Song of Songs 2:4b LXX) and the discovery of the infinite God - a never ending progress in knowledge and love for God.

The aim of Greek paideia was to lead the believers towards the highest goal of the human person, moral quality, virtue or wisdom (as Greek ideal, Marrou 1950:302-303). For Origen the highest virtue is love of God, which is therefore the goal of the Christian paideia (see Comm. Cant. Prologue 3; transl. Lawson 1957:44-45).

Origen understood the task of reading the Scriptures as guiding the readers on a spiritual journey. It is not surprising, therefore, that he will be attentive to those passages in the Scriptures about journeys, especially about Abraham (see Comm. Jo. 13:346; 20:67,68,124) and the exodus and wanderings in the desert (Torjesen 1986:73-77).

\section{The challenge of reading Origen's reading process}

Origen sees the Scriptures as the embodiment of the Logos. Therefore, just as the people meeting Jesus during his earthly life were challenged to go beyond his outer appearance as a human being to the divine presence, so too readers will have to go beyond the 'earthen treasures of paltry language' to hear the teachings of the Logos. Origen goes about this process in a systematic way. Torjesen (1986:138-147) concludes her study on Origen's hermeneutical procedure and theological method by identifying four steps in his approach. In the first step, he explores the grammatical sense of the text. In a second step, he moves to the 'event' or 'history' to which the 'letter' refers. The 'history' which is envisaged is the involvement of Logos in human history. Origen understood the 'letter' in a specific way, as a text written by the saints, who were attuned to the manifestations of the Logos and wrote with the aim that the readers of the text may also encounter the Logos in their own historical context. 'The words are written to be understood in a spiritual way' (Torjesen 1986:139). This means that the narratives, psalms and so on, are symbolic reports of encounters with the universal Logos. Therefore, these texts 'can become the model for succeeding experiences of the Logos since the pedagogy of the Logos is the same in all times' (Torjesen 1986:140-141). 'It is the historical pedagogy of the Logos as the content of the historical-literal sense which forms the basis for the spiritual sense' (Torjesen 1986:141). It is in this precise sense that Origen moves from 'history' to spiritual truth. This move to spiritual truth is the third step. It is achieved in two possible ways, allegory and historical generalisation. Allegory discovers a universal truth in the symbolic representations of history in the Scriptures and historical generalisation, for instance, a challenge to the sinners in Jeremiah's time, can be seen as the way of the Logos in all situations. The fourth step 'is the transition from the doctrine of the Logos within the world of Scripture to the doctrine of the Logos present within the world of the hearer' (Torjesen 1986:146). This is a gradual process by which the 
person becomes godlike through the knowledge of God and thereby is able to know God. ${ }^{17}$ This shows the pastoral focus of exegesis:

The progress of the soul toward perfection, participation in the Logos - in his universal pedagogy - is made possible through exegesis of the sacred text. It is the ministerial task of exegesis in the church to discover the presence of Christ the Logos in Scripture, who through his teachings (the progression of spiritual doctrines) completes the work of redemption in each individual soul (divinization through knowledge).

(Torjesen 1986:147)

The aim of the whole process of reading is participation or even identification with the Logos. This can be briefly illustrated by means of some passages from Origen's commentaries on the Gospel of John (Comm. Jo. 1:22-28) and the Song of Songs (Comm. Cant. Prologue 4). For Origen, the text of John is the fruit of the working of the Logos within him. No one can understand the text fully as expression of the Logos unless one becomes like John, who was intimately related to the Logos as the Logos is related to the Father (Jn 13:23 and 25 recall 1:18; Comm. Jo. 32:264). ${ }^{18}$ Furthermore, becoming like John means in fact even to become Jesus, as Jesus gave John to his mother as Mary's son and his mother to John as John's mother. ${ }^{19}$ Origen first explains this kind of identity by referring to Galatians 2:20: 'It is no longer I who live, but Christ who lives in me.' ${ }^{20}$ In the next paragraph, he adduces 1 Corinthians 2:16 and 12, where Paul speaks of us having the 'mind of Christ', which enables us to know the gifts of God. ${ }^{21}$ The understanding that Origen speaks of is ultimately the fruit of the union or identification of the reader with the Logos. In the reading of the Scriptures as gospel, the Logos himself approaches the home of the readers and knocks in order to be allowed to enter $(\operatorname{Rv} 3: 20) .{ }^{22}$

Origen discovers this process of transformation, first of all, in the inspired writers themselves and this same process has to be repeated in the readers. For instance, Origen sees Solomon, the author of the Song of Songs, as having gone through such a process, as one who has been fully transformed into a participant in the love song of the Logos:

And the fact that in the Song of Songs, where now perfection is shown forth, he [Solomon] describes himself neither as Son

17.As Torjesen (1986:147) reminds us, 'Knowledge has this mystical-contemplative character not only in Origen but within the Hellenistic world generally. Knowledge is only possible through similarity. Like is known by like'.

18.'The charism of the interpreter is the same as that of the inspired author ... and one can only interpret the Gospel if one has in oneself the nous, the mind of Christ, which the Spirit gives ...' (Crouzel 1989:73).

19.'For indeed everyone who has been perfected "no longer lives, but Christ lives in him", and since "Christ lives" in him, it is said that of him to Mary, "Behold you son", the Christ' (Comm. Jo. 1, 23; transl. Heine 1989:38).

20.The theme of Christ living in us (GI 2:20) is very important for Origen. According to him, Christ must be born and develop in each of us: 'If the soul is to give birth to the Word, then Mary is the model: "And every soul, virgin and uncorrupted, which conceives by the Holy Spirit, so as to give birth to the Will of the Father, is the mother of Jesus" (Fr. Matt. 281)' (Crouzel 1989, 124).

21.'What also must we say? For who will understand these matters accurately must say truthfully, "But we have the mind of Christ, that we may know the graces that have been given us by God"' (Comm. Jo. 1, 24; transl. Heine 1989:38).

22.But if the writings of Paul were gospel, it is consistent with that to say that Peter's writings also were gospel and, in general, those which present the sojourn of Christ and prepare for his coming and produce it in the souls of those who are willing to receive the Word of God who stands at the door and knocks and wishes to enter their souls (Comm. Jo. 1, 26; transl. Heine 1989:39). of David, nor as king, enables us to say further that, since the servant has been made the lord, and the disciple as the master, the servant obviously is such no longer: he has become as the lord. Neither does the disciple figure as a disciple when he has been made as the master; rather, the sometime disciple is in truth as the master now, and the sometime servant as the lord.

(Comm.Cant. Prologue 4; transl. Lawson 1957:54)

This ascent from the literal (Torjesen's steps 1 and 2) to the spiritual (steps 3 and 4) is ultimately the work of God. He leads us through Christ in the Holy Spirit to an ever deeper encounter and a corresponding transformation into the likeness of the Logos (Comm. Jo. 1:89). In the next section, the challenge to understand the core of the Scriptures will be more fully articulated, that is, that God is love and that love of God and love of neighbour are the summary of the Law and the Prophets. ${ }^{23}$

\section{Reading as struggle to understand and embody love, the goal of the Christian paideia}

Origen saw no problem in the historical distance between the meaning of the text in its origin and the meaning for the present reader. His focus was fully on the distance between the literal meaning and a worthy and fruitful meaning for today. ${ }^{24}$ However, this movement beyond the letter is often difficult and he describes it as a struggle with the words (see Cox 1988:165-178). What Origen is searching for is not mere doctrine, but to open the readers to the divine activity in their lives. A fundamental dimension of this process is the reciprocal relationship between 'understanding' and 'embodying.' In other words, the more the lives of the readers are embodying the divine life of love, the better they will understand the divine words about love, according to the well known principle that 'only like knows like.' Understanding the Scriptures is therefore an existential process and as a consequence, a gradual and always imperfect understanding. As is well known, Origen imagined this progress of conversion as involving three basic steps:

- moral purification

- recognition of our created condition and the discovery of the infinite God

- never ending progress in knowledge and love for God. ${ }^{25}$

Spiritual understanding of the Scriptures can, therefore, only be an anticipation of the face to face understanding of the apocatastasis.

In his Commentary on the Song of Songs, Prologue 2, Origen begins by recalling that the Greeks and many sages have

23.Obviously, Origen regularly refers to 1 John 4:8 (12 times according to Biblia Patristica) and Matthew 22:37-40 (48 times according to the Biblia Patristica).

24.'The consistency which exists between Moses and Jesus is at bottom the consistency of God's activity (and, therefore, an identity), as we learn in Contra Celsum 7.25 and, as such, exhibits the character of a temporal manifestation of
the eternal, whose revealed content can only be expounded from one age to the next, never definitively and finally articulated. This fact arises from the character of the biblical language itself with its polyvalence and obscurity of multi-layered of the biblical language itself with its polyvalence and obscurity of multi-layered
significations, but it comes also from the fact that the very act of exposition is always to some extent contaminated by the imperfection of the expositor who is not yet without sin' (Gorday 1988:334).

25.For a fuller discussion of these three stages, see Decock (2010:19-23). 
explored in dialogue form the nature of love. He asserts that:

The power of love is none other than that which leads the soul from earth to the lofty heights of heaven and that the highest beatitude can only be attained under the stimulus of love's desire.

(transl. Lawson 1957:24)

However, dealing with this God-given dynamism is both dangerous and difficult. It is dangerous, because it can easily be misunderstood in a vicious and carnal sense, as amongst some Greeks. Origen, therefore, exhorts his readers to pray:

So that we, out of these things that have been written, may be able to make clear a wholesome meaning in regard to the name and nature of love and one that is apt for the building up of chastity.

(transl. Lawson 1957:24)

Origen is then at pains to distinguish passionate love from charity. Charity, in the proper sense of the word, is the passion directed towards God. In a derived and secondary way, it is directed towards ourselves and our neighbour. However, it is a misnomer if we speak of love for money, pleasure or anything connected with corruption and error. With this understanding of charity Origen can then state:

All the same, you must understand that everyone who loves money or any of the things of corruptible substance that the world contains, is debasing the power of charity, which is of God, to earthly and perishable objects and is misusing the things of God by making them serve purposes that are not his; for God gave the things to men to be used, not to be loved.

(transl. Lawson 1957:35) ${ }^{26}$

An important aim of reading the Scriptures for Origen is to let the Logos bring order in our loves. He comments extensively on the line in the Song of Songs 2:4LXX: $\tau \dot{\alpha} \xi \alpha \tau \epsilon$

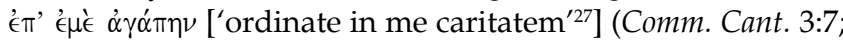
transl. Lawson 1957:187-195; Hom. Cant. 2:8; transl. Lawson 1957:294-297). Origen envisages the action of the Logos in the lives of readers as a 'dart of love' (Isa 49:2; see Lawson 1957:315, notes 33 and 34). In fact, he reads the last part of


also in that sense, as can be seen from the translations of Rufinus and Jerome, 'quia vulnerata caritatis ego'. Origen thinks of the scene of the disciples on the road to Emmaus as the model for such experiences:

How blessed is it to be wounded by this dart! Those men who talked together, saying to each other: Was not our heart burning within us in the way, whilst he opened to us the Scriptures? had been wounded by this dart. If anyone has been wounded by our discourse, if any is wounded by the teaching of the Divine Scripture, and can say, 'I have been wounded by love,' perhaps he follows the former and the latter.

(Hom. Cant. 2:8; transl. Lawson 1957:297)

Furthermore, exploring the meaning of love is difficult. It is as difficult to fathom as God self, who is charity. Just as no one knows the Father except the Son and no one knows the

26.This passage seems to be the source of the well known distinction in Augustine of uti and frui and which has aroused so much discussion until the present time: se De Doctrina Christiana 1,22.20 and 33.37; on the present discussion, see Dupont (2006).

27.This is how Rufinus and Jerome translated the line into Latin in the translation of Origen's Commentary (Rufinus) and Origen's Homilies (Jerome). Origen's Greek text is no longer available to us. Jerome's own translation of this line in what late became the Vulgate differs as it follows the Hebrew text available to him.
Son except the Father, we are dependent on the Spirit, who 'goes about trying to find souls worthy and able to receive the greatness of this charity' (Comm.Cant, Prologue 2; transl. Lawson:39). How are the readers to understand the true image of love into which they are called to be transformed? We can see how Origen struggled to understand how God could be seen as love, because in his philosophical context God was seen as self sufficient and beyond any need or feelings or passions. Fernandez Eyzaguirre (2006:135-147 ) has pointed out a very interesting text in which we see how Origen struggles, against the common and easy solutions, to understand both God's impassibility and God's passibility:

I am going to give an example of men which, if the Holy Ghost permits, I shall then apply to Jesus Christ and God the Father. When I speak to a man and beg him for something, so that he may have pity on me, if he has no mercy he will not suffer (nihil patitur) for what I have said; if on the contrary, he is sensitive and there is nothing in him to harden his heart, he will listen to me and have mercy on me and his entrails shall quiver with my pleading. I want you to understand something similar regarding our Saviour: He descended to earth because he had mercy on the human gender, and so bore our passions before suffering on the cross and deigning to assume our flesh (passiones perpessus est nostras, antequam crucem pateretur et carnem nostram dignaretur assumere). If he had not suffered, he would not have come to share our human life. He suffered first and then he descended and revealed himself (primum passus est, deinde descendit et visus est). Now, which was this passion he suffered for us? It is the passion of charity (caritatis est passio). For the very Father, God of the universe, who is magnanimous, full of mercy and compassionate (Ps 102,8), doesn't he also suffer in some way? Do you ignore that, when he manages human realities, he suffers human passions? Verily the Lord, your God, assumed your manners (mores tuos) as a man would assume his son (Dt 1,31). So God assumes our manners as the Son of God bears our passions. The Father himself is not impassible (Ipse Pater non est impassibilis). If begged, he pities and condoles, he suffers for a certain charity (patitur aliquid caritatis), and gets to [conditions] in which He cannot agree with the magnitude of his nature and, for our sake, he bears human passions (et fit in iis in quibus iuxta magnitudinem naturae suae non potest esse, et propter nos humanas sustinet passiones).

(Hom. Ezech. 6,6; transl. Fernandez Eyzaguirre 2006:139-140)

Fernandez Eyzaguirre (2006) comments on this last sentence:

He admits that God, out of mercy, exercising his liberty, surpasses the limits imposed upon him by the greatness of his being, since, for the economy, God becomes [fit] what is incompatible with the magnitude of his nature.

(Eyzaguirre 2006:147)

Another question Origen had to struggle with was how God's love can be reconciled with the experience of suffering and the understanding of punishment. Inspired by Proverbs 3:12 and the common view on punishment, Origen sees sufferings as saving punishments (see selection of texts in Von Balthasar 1984:nrs 909-924, 934-951). Will God be able to bring all people to salvation? Will the punishment be effective and will all suffering and inequality between persons come to an end? Origen seems confident that all will be saved:

But in this purification which is obtained through the punishment of fire, how much time and how many ages of punishment may be required of a sinner, only he can know to whom 'the Father 
has given all judgment' (Jn 5:22), who so loves his creation that for it 'he emptied himself of the form of God, taking the form of servant, humbling himself unto death' (cf. Phil 2:6-8), desiring 'all men to be saved and to come to the knowledge of the truth' (2 $\operatorname{Tim} 2: 4)$.

(Comm. Rom. 8:12; transl. von Balthasar 1984:nr 955)

However, this knowledge may not be beneficial to all, as for some this foreknowledge may 'cause them to relax and no longer resist sin the way they should, since what was foretold would be happening in any case' (Comm. Gen. Fragm 3:7; transl. von Balthasar 1984:nr 960). Origen concludes in that same passage, 'Thus it is fitting for us not to know whether we will turn out good or bad' (Comm. Gen. Fragm 3:7; transl. von Balthasar 1984:nr 960). ${ }^{28}$

It was seen that, for Origen, understanding the Scriptures for our times, particularly, understanding love, is a mighty struggle. He struggled with the limitations that his culture was imposing on God and against the deviations in the understanding of love that he saw in his culture. From the point of view of our present culture, his understanding of love may be seen as suffering from otherworldliness and from a negative attitude towards the body and the whole material reality. Origen would certainly be the first to admit that he is still on the way, that he has not fully understood the implications of the challenge to become like God, to become assimilated to the Logos, the true image of God. However, his insistence that we view this material world and the body as symbols of the divine and not as mere objects invites us to a nuanced assessment and may challenge and stimulate our own understanding. ${ }^{29}$

\section{Conclusion}

Origen lived at a time long before we became critically aware of the cultural differences between the world in which the biblical writings originated and the world of the present readers. At that time there was no vivid sense of the difference, or even tension, between what the text 'meant' and what it 'means'. For Origen, as for all his predecessors, the focus was simply on what the text 'means.' However, without knowing it, Origen was involved in a process of demythologising and inculturating the message for his readers. But, more than that, in Origen's view the 'letter' not only conveys a message, but it has to become a powerful and transforming 'dart of love', wounding the readers so that they 'will be kindled with the blessed fire of his love' (Comm. Cant. Prologue 2: transl. Lawson 1957:30). Discovering these

28.Crouzel (1989:265) cautions interpreters of Origen on the issue of the apocatastasis: 'If Origen added anything to what Paul said in 1 Cor. 15, 23-28, it pocatastasis: 'f Origen added anything to what Paul said in 1 Cor. 15, 23-28, it could only be a great hope. Certainty about a universal apocatastasis would be in contradiction to the authenticity of the free will with which God has endowed mankind'. He concludes the discussion with words which confirm Origen's approach to the understanding of the Scriptures as a struggle and often tentative: 'A man as passionate about God and divine knowledge as Origen does not reach God by system, but by all the means, intellectual and mystical, that are at his disposal, even if these means do not form a system ruled by rationalist logic and in the dark places of the faith that is ours he is not ashamed to feel this way. But that groping is much more moving ad interesting than the best constructed systems' (1989:266).

29.According to Crouzel (1989:107): 'It is of the nature of created things that they must be left behind: the soul in its soaring must aim far beyond them. So it is insofar as we will to get beyond them that the created things show the Creator and ins for cor created things: the the show the way to true eternity, instead of conferring on them, by taking them for something that they are not, an absolute and eternal status which they do not have. Such is the sin of the idolaters ...' On Origen's appreciation of the body, see Cels. 4:23 and the comment by Brown (1988:160-177). symbolic meanings in the words, sentences and scenes of the Scriptures emerges in the process of personal conversion and transformation. 'Ascending' into the Scriptures goes hand in hand with the spiritual ascent of the reader along the three basic stages of spiritual growth. Whilst Origen focuses on the personal ascent into the meaning and reality of love, we now realise more fully that this always takes place in interaction with our changing socio-cultural context, which itself is grappling with issues of equality, human rights, freedom and dignity of the person as dimensions of the meaning of love. Presently, in our world and culture, humanity is still searching and struggling to figure out not only what a just human community is meant to be like but, beyond that, how to let this world become a loving community. In the vision of Origen, this is the ultimate aim of the study of the Scriptures. It is in the struggle with the words of the Scriptures as participants in the currents of our present socio-cultural context that we meet the Logos who leads us towards an ever fuller understanding of and participation in, the God who is love.

\section{References}

Alici, L., 1996, Sign and language', in J.E. Rotelle (ed.), 1996, Teaching Christianity: De Dotrina Christiana, pp. 28-53, New City Press, New York (The works of Saint Augustine: A translation for the 21st century 1, 11).

Aune, D.E., 1983, Prophecy in Early Christianity and the Ancient Mediterranean world, Eerdmans, Grand Rapids, MI.

Balthasar, H.U., von 1984, Origen: Spirit and fire: A thematic anthology of his writings, T \& T Clark, Edinburgh.

Barkley, G.W., 1990, Origen: Homilies on Leviticus 1-16, The Fathers of the Church, vol. 83, The Catholic University of America Press, Washington, DC.

Biblia Patristica: Index des citations et allusions bibliques dans la littérature patristique [Index of biblical citations and allusions in the patristic literature], 1980, vol. 3, Origène, Éditions du Centre National de la Recherche Scientifique, Paris.

Brown, P., 1988, The body and society: Men, women and sexual renunciation in early Christianity, Columbia University Press, New York.

Brown, R.E. \& Collins, R.F., 1990, 'Canonicity', in R.E. Brown, J.A. Fitzmyer \& R.E. Murphy (eds.), The New Jerome Biblical Commentary, pp. 1034-1054, Geoffrey Chapman, London.

Brown, R.E. \& Schneiders, S., 1990, 'Hermeneutics', in R.E. Brown, J.A. Fitzmyer \& R.E. Murphy (eds.), The New Jerome Biblical Commentary, pp. 1146-1165, Geoffrey Chapman, London.

Candler, P.M. Jr., 2006, Theology, rhetoric, manuduction, or reading Scripture together on the path to God, Eerdmans, Grand Rapids, MI.

Colson, F.E. \& Whitaker, G.H., 1985, 'On Mating with Preliminary Studies', in Philo in ten volumes (and two supplementary volumes), vol. 4, pp. 449-551, Harvard University Press, Cambridge, MA.

Cox Miller, P., 1988, 'Poetic Words, Abysmal Words: Reflections on Origen's Hermeneutics', in Ch. Kannengieser \& W.L. Petersen (eds.), Origen of Alexandria: His world and his legacy, Christianity and Judaism in Antiquity, vol. 1, pp. 165-178, University of Notre Dame Press, Notre Dame, IN.

Crombie, F., 1982, 'Origen, de pincipiis [On First Principles]', in A. Roberts, J. Donaldson \& A.C. Coxe (eds.), The ante-nicene fathers: translations of the fathers down to A.D. 325 , vol. 4, pp. 239-384, n.p.

Crouzel, H., 1956, Théologie de l'image de Dieu chez Origène [Theology of the image of God in Origen], Éditions Montaigne, Paris.

Crouzel, H., 1989, Origen, transl. A.S. Worall, T\&T Clark, Edinburgh

Dawson, D., 1999, 'Figure, allegory', in A.D. Fitzgerald (ed.), Augustine through the ages: An encyclopedia, pp. 365-366, Eerdmans, Grand Rapids, MI.

Decock, P.B., 1993, 'The reading of sacred texts in the context of early Christianity', Neotestamentica 27, 263-282.

Decock, P.B., 2008, 'Allegorising: The relevance of an old method of interpretation' Acta Theologica, Supplementum 11, 1-19.

Decock, P.B., 2010, 'Origen's Christian approach to the Song of Songs', Religion \&Theology 17, 13-25. doi: 10.1163/157430110X517898

Dively Lauro, E.A., 2004, 'Fall, The', in J.A. McGuckin (ed.), The Westminster Handbook to Origen, Westminster Handbooks to Christian Theology, pp. 100-101, Westminster John Knox Press, Louisville, KY.

Dupont, A., 2006, 'To Use or to Enjoy Humans? Uti and Frui in Augustine', in F. Young M. Edwards \& P. Parvis (eds.), Augustine - Other Latin Writers: Papers Presented at the Fourteenth International Conference on Patristic Studies, Held in Oxford 2003, Studia Patristica, vol. 43, pp. 89-93, University Press, Leuven. 
Fernandez Eyzaguirre, S., 2006, 'Passio caritatis according to Origen, in Ezechielem Homiliae VI in the light of Dt 1:31', Vigiliae Christianae 60, 135-147. doi: Homiliae $1163 / 157007206777346873$
10.1

Fishbane, M., 1985, Biblical interpretation in Ancient Israel, Clarendon, Oxford.

Fishbane, M., 1988, 'Authority and Interpretation of Miqra at Qumran', in M.J. Mulder \& H. Sysling (eds.), Mikra: Text, translation, reading and interpretation of the Hebrew Bible in Ancient Judaism and Early Christianity, Compendia rerum iudaicarum ad Novum Testamentum, vol. 2,1, pp. 339-377, Van Gorcum, Assen.

Fishbane, M., 1989, The Garments of Torah: Essays in Biblical Hermeneutics, Indiana Studies in Biblical Literature, Indiana University Press, Bloomington, IN.

García Martínez, F., 1994, The Dead Sea Scrolls translated: The Qumran texts in English, Brill, Leiden.

Gorday, P.J., 1988, 'Moses and Jesus in Contra Celsum 7.1-25: Ethics, History and Jewish-Christian Eirenics in Origen's Theology', in Ch. Kannengieser \& W.L. Petersen (eds.), Origen of Alexandria: His World and His Legacy, Christianity and Judaism in Antiquity, vol. 1, pp. 313-336, University of Notre Dame Press, Notre Judaism in
Dame, IN.

Hadot, I., 1987, 'Les introductions aux commentaires exégétiques chez les auteurs néoplatoniciens et les auteurs chrétiens' [The introductions to the exegetical commentaries in neoplatonic and Christian authors], in M. Tardieu (ed.) Patrimoines religion du livre, pp. 99-122, Cerf, Paris.

Harl, M., 1958, Origène et la fonction révélatrice du verbe incarné [Origen and the revelatory function of the Word Incarnate], Patristica Sorbonensia, vol. 2, Seuil, Paris.

Heine, R.E., 1982, Origen: Homilies on Genesis and Exodus, The Fathers of the Church, vol. 71, The Catholic University of America, Washington, DC.

Heine, R.E., 1989, Origen: Commentary on the Gospel of John according to John Books 1-10, The Fathers of the Church, vol. 80, The Catholic University of America, Washington, DC.

Heine, R.E., 1995, 'The introduction to Origen's Commentary on John compared with the introductions to the ancient philosophical commentaries on Aristotle' Origeniana Sexta, Bibliotheca ephemeridum theologicarum lovaniensium, vol. 118, pp. 3-12, Peeters, Leuven.

King, J. Ch., 2005, Origen on the Song of Songs as the Spirit of Scripture: The Bridegroom's Perfect Marriage-Song, Oxford Theological Monographs, Oxford University Press, Oxford, WI.

Koch, D.A., 1986, Die Schrift als Zeuge des Evangeliums: Untersuchungen zur Verwendung und zum Verständnis der Schrift bei Paulus, Beiträge zur historischen Theologie, vol. 69, Mohr (Paul Siebeck), Tübingen

Lawson, R.P., 1957, Origen: The Song of Songs: Commentary and Homilies, Ancient Christian Writers, vol. 26, The Newman Press, Westminster, MD.
Lubac, H., de, 1950, Histoire et Esprit: L'Intelligence de l'Écriture d'après Origène [History and Spirit: The Intelligence of Scripture by Origen], Éditions Montaigne, Paris.

Marrou, H.-I., 1950, Histoire de I' éducation dans l'Antiquité [History of education in antiquity], 2nd edn., Seuil, Paris.

McGuckin, J.A., 2004, 'Image of God', in J.A. McGuckin (ed.), The Westminster Handbook to Origen, Westminster Handbooks to Christian Theology, pp. 131-134, Westminster John Knox Press, Louisville, KY.

Mulder, M.J., 1988, 'The transmission of the biblical text', in M.J. Mulder \& H. Sysling (eds.), Mikra: Text, translation, reading and interpretation of the Hebrew Bible in Ancient Judaism and Early Christianity, CRI 2,1, pp. 87-136, Van Gorcum, Assen.

Neuschäfer, B.,1987, Origenes als Philologe, Schweizerische Beiträge zur Altertumswissenschaft, vol. 18, Reinhardt, Basel.

Neusner, J., 1979, 'The formation of Rabbinic Judaism: Yavneh (Jamnia) from A.D. 70 to 100 ', in W. Haase (ed.), Aufstieg und Niedergang der römischen Welt, II: Principat 19.2. Religion (Judentum: Allgemeines; Palästinisches Judentum), Principat 19.2. Religion (Judentum: Allgemeines; Palastinisches Judentum), Aufstieg und Niedergang der römischen Welt: Geschichte
Spiegel der neueren Forschung, pp. 3-42, de Gruyter, Berlin

Neusner, J., 1984, Messiah in context: Exegesis in formative Judaism, The Foundations of Judaism: Part 1: Method, Fortress, Philadelphia, PA.

Norris, F.W., 2004, 'Apokatastasis', in J.A. McGuckin (ed.), The Westminster Handbook to Origen, Westminster Handbooks to Christian Theology, pp. 59-62, Westminster John Knox Press, Louisville, KY.

O’Donnell, J.J., 1992, Augustine: Confessions, vol. 1, Introduction and text, Clarendon Press, Oxford.

O'Leary, J.S., 2004, 'Grace', in J.A. McGuckin (ed.), The Westminster Handbook to Origen, Westminster Handbooks to Christian Theology, pp. 114-117, Westminste John Knox Press, Louisville, KY.

Runia, D.T., 1987, 'Further observations on the structure of Philo's Allegorical Treatise', Vigiliae Christianae 41, 105-138. doi: 10.1163/157007287X00012

Stendahl, K., 1962, 'Biblical Theology, Contemporary', in G.A. Buttrick (ed.), The Interpreter's Dictionary of the Bible, vol. 1, pp. 418-432, Abingdon Press, Nashville, TN.

Simonetti, M., 1994, Biblical interpretation in the Early Church: An historical introduction to Patristic exegesis, T\&T Clark, Edinburgh.

Torjesen, K.J., 1985, 'Body, soul, and spirit in Origen's Theory of Exegesis', Anglican Theological Review 67, 17-30.

Torjesen, K.J., 1986, Hermeneutical procedure and theological method in Origen's exegesis, Patristische Texte und Studien, vol. 28, De Gruyter, Berlin. doi: 10.1515/9783110881981.148 